\title{
АКТУАЛЬНІ ПРОБЛЕМИ ОВОЛОДІННЯ ПРАКТИЧНИМИ НАВИЧКАМИ $З$ ПЕДІАТРІЇ НА ЗАСАДАХ БОЛОНСЬКОГО ПРОЦЕСУ
}

О. П. Пахольчук

Запорізький державний медичний університет

\section{ACTUAL PROBLEMS OF THE PRACTICAL SKILLS ACHIEVEMENT IN PEDIATRICS IN THE CONDITIONS OF THE BOLOGNA PROCESS}

\author{
O. P. Pakholchuk
}

\author{
Zaporizhzhia State Medical University
}

\begin{abstract}
У статті представлений досвід викладання педіатрії у Запорізькому державному медичному університеті, визначені актуальні проблеми оволодіння практичними навичками 3 педіатрії в умовах кредитно-модульної системи навчання; обгрунтована методика використання посднання імітаційної та традиційної освіти.

The article presents experience of the pediatrics teaching in Zaporizhzhia State Medical University, actual problems of the practical skills achievement in the conditions of the Bologna process were indicated. Methodology of the combination of the imitative and traditional education was presented.
\end{abstract}

Вступ. Формування компетентної професійної готовності майбутнього лікаря неможливе без занять біля “ліжка хворого" [1, 4, 5]. Для досягнення максимального ефекту необхідно вміло поєднувати засвоєння теоріїз практичним ії використанням. Цей підхід дозволить підвищити загальну мотивацію до знань у студентів та виявити помилки. В процесі навчання студент набуває практичні навички, які буде використовувати впродовж всього подальшого життя. Саме тому важливо вдало закласти їх основу, що стане запорукою успішної професійної діяльності. Проте останнім часом ми стикаємось із тим фактом, що принципи деонтології та права пацієнта деколи обмежують спілкування студентів та хворих. 3 іншого боку, кредитно-модульна система навчання передбачає відведення великої кількості часу на самостійну роботу. Підходи до процесу оволодіння практичними навичками постійно потребують удосконалення [2, 4-6]. Використання новітніх технологій та методик $\epsilon$ не тільки вимогою сучасності, а й джерелом для створення нових видів навчальної діяльності. Ïх розширення за рахунок спеціальних тренажерівсимуляторів дозволить урізноманітнити навчання, забезпечить оперативність контролю за набуттям нових знань, аналізом [3].
Основна частина. Метою роботи було проаналізувати результати викладання педіатрії у Запорізькому державному медичному університеті і визначити та дослідити актуальні проблеми оволодіння практичними навичками 3 педіатрії на засадах Болонського процесу в умовах кредитно-модульної системи навчання; обгрунтувати методику використання поєднання імітаційної та традиційної освіти. Використовувався теоретичний аналіз та вивчення літератури, нормативних та програмно-методичних документів. Також був використаний самоаналіз та оцінка накопиченого досвіду. Основу склав досвід викладання педіатрії на кафедрі факультетської педіатрії Запорізького державного медичного університету у 2006-2014 роках. Предметом дослідження були методики оволодіння практичними навичками традиційної та імітаційної освіти.

Програма $з$ предмета "Педіатрія" не передбачає окремих занять для оволодіння навичками, але модульна система ефективно інтегрує їх у собі. Базові діагностичні та лікувальні маніпуляції включені до кожної теми занять та доповнюють теоретичну підготовку. Наскрізна програма викладання педіатрії та міждисциплінарний підхід передбачає, що студент на кожному курсі або кафедрі оволодіває новими навичками, які приєднуються до існуючого базису технік.

() О. П. Пахольчук 
Що нагадує багатошарове утворення. Не менш важливим є використання наскрізних навчальних підходів, що передбачає викладання навичок з медичних маніпуляцій, які не мають залежності від віку пацієнта [4].

Аналіз форм для модульного контролю показав, що “виживання” знань, набутих на теоретичних кафедpax, є низьким, а середній бал за цими питаннями не перевищує трійки. Що, можливо, якраз пов'язано із відсутністю їх практичного пристосування під час вивчення. Адже просте запам'ятовування має лише тимчасовий ефект. В той час як використання усіх видів пам'яті: і зорової, і слухової, і механічної-сприяє формуванню стійких зв' язків нейронів головного мозку.

Відповідно до засад кредитно-модульної системи у структурі кожного заняття самостійна робота студентів становить від 40 до 60 \% часу і базується на засвоєнні тематичного матеріалу та фундаментальних знаннях [1]. Самостійна робота студентів молодших курсів неможлива без нагляду викладача, тоді як на останніх курсах може бути використана субординатура. Чисельність груп не дозволяє ефективно відпрацьовувати практичні навички на маленьких пацієнтах, оскільки займає багато часу, через це викликає незадоволеність батьків, що підкріплюється часто не відмінною підготовкою студентів до занять.

Студент - це активний учасник міжособистісної взаємодії, вміння спілкуватися з хворим, особливо малечею, також прищеплюється не одразу. Тому комунікативні навички при роботі з дітьми можливо відпрацювати лише у клініці. Відмінна практична підготовка студентів перед спілкуванням із пацієнтами дозволяє більше зосередитись на комунікативних моментах, ніж на самій методиці маніпуляцій. У подібних ситуаціях стало в пригоді використання імітаційної освіти $[3,6]$.

Новітні технології дозволяють створювати навчальні матеріали вищої якості, максимально наближені до прототипів, використання яких дозволить знизити навантаження на пацієнтів, ефективно використати відведений час для самостійної роботи. Імітаційна освіта студентів спрямована на оволодіння навичками обстеження хворого, проведення різноманітних медичних маніпуляцій. Виконувати маніпуляції на тренажері відповідно до алгоритму є необхідною вимогою. Порушення його в реальному житті принесе шкоду здоров'ю пацієнта, а у випадку із фантомом - матеріальну шкоду [3, 5]. Хоча другий варіант є менш негативним, проте навіть він є доволі неприйнятним, а отже, також буде стимулювати сту- дента до самоорганізації, проте не буде нести ризик для хворого. Що відповідає етичним принципам та сприяє збереженню поваги до студента-медика у колі хворих, яка останнім часом має доволі низький рівень через різні причини.

Слід відмітити можливість двосторонньої взаємодії між студентом та викладачем під час роботи із фантомами та демонстрації навичок, адже не все можна обговорювати впродовж клінічних розборів біля ліжка хворого з міркувань етики.

В оптимізації ефективності навчального процесу велику роль має контроль засвоєння матеріалу. Вкрай важливо оцінити знання та вміння 3 надання невідкладної допомоги дітям. Індивідуалізація освіти завдяки запровадженому комплексу навчальних засобів дозволяє ефективно та адекватно оцінювати надбані навички у багаточисельної групи студентів.

Таким чином, процес оволодіння студентами практичними навичками з предмета "Педіатрія" був поділений на етапи [1]. Перший - попереднє вивчення певної кількості навчального матеріалу, вивчення алгоритму, механізму дії. Другий - підготовка до занять шляхом самостійного тренінгу, самостійне відпрацювання уміння. На цьому етапі необхідна участь викладача, який має показати правильну техніку виконання, яку потім студент буде повторювати. Третій етап - відпрацювання навичок безпосередньо на пацієнтах. Остання ланка можлива лише із студентами останніх двох курсів навчання, оскільки вимагає високої професійної підготовки та виваженості дій. Медичні муляжі, фантоми та тренажери для тренування маніпуляцій, що складають основу імітаційної освіти, можуть бути використані на усіх етапах.

Висновки: 1. Розширення арсеналу засобів навчання дозволить урізноманітнити види навчальної діяльності студентів-медиків при вивченні педіатрії, інтенсифікувати традиційні методи освіти за рахунок візуалізації.

2. Підвищення якості викладання практичних навичок оптимізує та індивідуалізує процес підготовки якісних спеціалістів.

3. Успішність результату підкріплюється мотивацією студентів та забезпечується багаторазовим повторенням впродовж вивчення предмета на різних кафедрах та етапах оволодіння навичками.

4. Використання фантомного обладнання та медичних муляжів сприяє дотриманню етичних аспектів відносин між пацієнтом та студентом та знижує навантаження на пацієнтів клінік. 


\section{Список літератури}

1. Актуальні проблеми опанування практичних навичок на кафедрі загальної хірургії на засадах Болонської декларації / О. Ю. Іоффе [та ін.] // Мед. освіта. - 2012. - № 2. C. 81-84.

2. Захарченко Т. Роль наочності у процесі викладання професійно орієнтованих дисциплін / Т. Захарченко // Вища школа. -2013. - № 12. - С. 30-38.

3. Имитационное обучение в системе непрерывного медицинского профессионального образования / под ред. П. В. Глыбочко. - М. : Издательство Первого МГМУ им. И. М. Сеченова, 2012.-120 с.

4. Підходи до удосконалення процесу оволодіння практичними навичками слухачами різних форм навчання
НМАПО імені П. Л. Шупика / Н. В. Медведовська [та ін.] // Здоров’я суспільства. -2014. - Т. 3, № 1/2. - С. 71.

5. Паляцко К. Г. Методика оцінки оволодіння практичними навичками інтернами-хірургами на кафедрі хірургії післядипломної освіти / К. Г. Паляцко // Мед. освіта. -2013. -№ 4. - С. 66-68.

6. Пахольчук Т. М. Деякі елементи когнітивної технології навчання у викладанні дитячих інфекційних хвороб на V курсі / T. М. Пахольчук, О. В. Усачова // Актуал. питання фармац. та мед. науки та практики. - 2014. - № 1. C. 103-105.

Отримано 29.12.14 